Click www.researchjournal.co.in/online/subdetail.html to purchase.

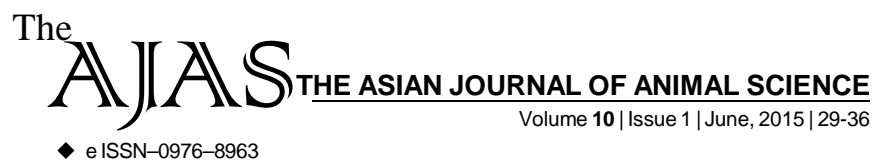

DOI : 10.15740/HAS/TAJAS/10.1/29-36 Visit us | www.researchjournal.co.in $\mathrm{S}$

RESEARCH ARTICLE.

\title{
Productive and reproductive performance of buffalo
}

RANJANA SACHAN, GOPAL SANKHALA AND JYOTI MANJUSHA

Author for Corresponding -

RANJANA SACHAN

Division of Extension Education,

Indian Veterinary Research

Institute, Izatnagar, BAREILLY

(U.P.) INDIA

See end of the article for

Coopted authors'
ABSTRACT...... The present study was carried out drawing a sample of 120 dairy farmers using random sampling from the three blocks of Unnao district of Uttar Pradesh and from each block two villages were selected randomly. Production and Reproduction is one of the most important considerations to determine the profitability of buffalo. The parameters of productive and reproductive performance of buffalo were as under: Average daily milk yield, $5.36 \pm 1.2$ lit./ day/buffalo, lactation length, $293.5 \pm 27.1$ days/buffalo, lactation milk yield, $1636.4 \pm 189$ lit./ buffalo, peak yield, $8.1 \pm 1.9$ lit./buffalo, dry period, $156.4 \pm 39.6$ days/buffalo, Age at first calving, $1482 \pm 162$ days/buffalo, Service period, $142 \pm 26$ days/buffalo, Service per Conception, $2.57 \pm 0.45$ times/buffalo and Calving interval was $450.2 \pm 35.1$ days/buffalo. The results showed that dry period and service period were found to be high which resulted in increase in inter-calving period, thereby leading to the increase in unproductive period among buffaloes of the study area.

KEY WORDS....... Dry period, Service period, Calving interval, Dairy farmers

HOW TO CITE THIS ARTICLE - Sachan, Ranjana, Sankhala, Gopal and Manjusha, Jyoti (2015). Productive and reproductive performance of buffalo. Asian J. Animal Sci., 10(1) : 29-36.

ARTICLE CHRONICLE - Received : 18.08.2014; Revised : 19.04.2015; Accepted : 03.05.2015 